\title{
МЕХКУНАРОДНО-ПРАВОВОЕ РЕГУЛИРОВАНИЕ ТРУДОВОЙ МИГРАЦИИ В ЕВРАЗИЙСКОМ РЕГИОНЕ: ПОПЫТКА ПРИБЛИЗИТЬСЯ К СВОБОДЕ ПЕРЕДВИХЕНИЯ РАБОТНИКОВ?
}

\begin{abstract}
Международно-правовое регулирование трудовой миграции в рамках региональных объединений Европейского союза и Евразийского экономического союза характеризуется своеобразием и отличается от универсальных моделей, сложившихся в рамках ООН. В статье дается сравнение терминов, используемых в Договоре о ЕАЭС с термином «работник», сложившимся в рамках практики Суда ЕС, формулируются отдельные предложения для интеграционных институтов ЕАЭС по учету опыта права ЕС в области обеспечения свободного передвижения работников. В результате исследования сделаны следующие выводы. Несмотря на влияние правового опыта ЕС в отношении формирующейся правовой системы Содружества, особенно в плане создания Экономического Союза и общего экономического пространства в рамках Таможенного союза и Евразийского экономического сообщества, реализация соответствующих договорных положений существенно отличается от правовой модели свободного передвижения в праве ЕС. Для целей развития экономической интеграции и обеспечения единого рынка труда в ЕАЭС было бы целесообразно: использовать широкое понимание термина «трудящийся государства-члена», применять опыт ЕС по запрету трудовой деятельности для нерегулярных трудовых мигрантов, дополнить Договор о ЕАЭС положением о запрете дискриминации трудящихся государств-членов по признаку гражданства, внести в Договор о ЕАЭС положения о правовом регулировании трудовой миграции граждан третьих стран. Желаемая модель интеграции в рамках ЕАЭС может быть тем более эффективной,
\end{abstract}

Рустем Шамилевич Давлетгильдеев - д.ю.н., доцент, академический координатор центра Жана Монне в области европейских исследований VOICES+, заместитель декана юридического факультета, Казанский федеральный университет, Казань, Россия. Электронная почта: roustem.davletguildeev@kpfu.ru 
если будет вбирать в себя лучший опыт, накопленный в других региональных интеграционных объединениях.

Ключевые слова: трудовая миграция, трудящийся государства-члена, Евразийский экономический союз, Европейский Союз, свобода передвижения работников

DOI: $10.17323 / 727-0634-2018-16-4-595-610$

Международно-правовое регулирование трудовой миграции в рамках региональных объединений Европейского союза и Евразийского экономического союза характеризуется своеобразием и отличается от универсальных моделей, сложившихся в рамках ООН. При детальном рассмотрении развития регионального сотрудничества государств на постсоветском пространстве, можно заметить сходства в стилистике текстов международных соглашений, в создании определенных инструментов интеграции, в частности, единого рынка труда и обеспечения свободы передвижения работников. Такие положения содержатся в основных документах Содружества Независимых Государств, а также в актах, предшествующих созданию Евразийского экономического союза. В Договоре о ЕАЭС есть специальная глава, посвященная трудовой миграции, формулировки некоторых ее положений также имеют параллели с правом ЕС, в большей или меньшей степени. Стремление создать единый рынок труда в ЕАЭС привело к отходу от классического для международного права термина «трудящийся-мигрант» в пользу интеграционного термина «трудящийся государств-члена».

В статье дается сравнение терминов, используемых в Договоре о ЕАЭС с термином «работник», сложившимся в рамках практики Суда ЕС, формулируются отдельные предложения для интеграционных институтов ЕАЭС по учету опыта права ЕС в области обеспечения свободного передвижения работников с учетом позиции, высказанной М.В. Лушниковой и А.М. Лушниковым: «Модель интеграции..., избранная и проводимая ЕC, не может быть заимствована без предварительной адаптации с учетом сложившихся на постсоветском пространстве правовых традиций» (Лушникова и др. 2018:43). Исследование построено на принципах сравнительно-правового и формально-юридического методов и развивается в исторической перспективе.

\section{Влияние правового опыта Европейского Союза на формирование модели правового регулирования трудовой миграции в Евразии}

В статье 19 Устава СНГ 1993 г. (Российская газета 1993), определяющего направления сотрудничества государств-участников в экономической и социальной областях, закреплено формирование общего экономического пространства на базе рыночных отношений и свободного перемещения товаров, 
услуг, капиталов и рабочей силы. Такая формулировка близка по содержанию к тексту п. «с» ст. 3 Договора, учреждающего Европейское Экономическое Сообщество: «деятельность Сообщества предусматривает < .. > устранение между государствами-членами препятствий свободному движению лиц, услуг и капиталов» (Европейский Союз 1994: 100). Правовой формой закрепления и детализации одного из направлений сотрудничества, установленного в статье 19 Устава СНГ, стал Договор об Экономическом Союзе 1993 г. (Бюллетень... 1995). При его характеристике Ю.А. Тихомиров писал, что «в рамках СНГ правовое влияние ЕС ощутимо» (Тихомиров 1993: 88). Эта «ощутимость» не означает идентичности положений, но свидетельствует о значении, придаваемом правовому опыту, накопленному государствами Западной Европы в рамках Европейского Союза при правовом оформлении основ экономической интеграции между государствами-членами СНГ.

В основу фундаментальной экономической свободы передвижения лиц в праве ЕС положен принцип, зафиксированный в ст. 18 Договора о функционировании Европейского Союза (далее - ДФЕС), запрещающий всякое проявление дискриминации по признаку национального гражданства. Универсальный характер принципа проявляется в том, что он равно применим к свободе передвижения товаров, услуг и капиталов. Применительно к свободному передвижению принцип недискриминации конкретизируется в п.2 ст. 45 ДФЕС, определяя области трудовых отношений, в которых всякая дискриминация по признаку национальности должна быть устранена: «Свобода передвижения трудящихся включает устранение всякой дискриминации, основанной на национальности между трудящимися государствчленов, в том, что касается трудоустройства, вознаграждения и других условий труда». В прямом проявлении дискриминация запрещена не только в учредительном Договоре, но и в Регламенте 492/2011 о свободе передвижения внутри Союза, а также в Директиве 2004/38 о праве граждан ЕС и членов их семей свободно передвигаться и проживать на территории государств-членов (European Union Law 2011: ст. 7-9; 2004: ст. 24). Действие принципа недискриминации последовательно подтверждалось в решениях Суда ЕС (например, дела 152/73 Sotgiu [1974], C-234/94 O’Flynn [1996]).

Существенный интерес в плане использования опыта ЕС представляет Договор о Таможенном союзе и Едином экономическом пространстве 1999 г. (далее - Договор о ТС и ЕЭП), одной из целей которого выступает все то же эффективное функционирование общего (внутреннего) рынка труда (Coбрание... 2001). Вопросам общего рынка труда и социальной политики посвящен раздел 6 в главе о создании единого экономического пространства. Формулировки отдельных его статей напоминают и даже повторяют положения Договора о функционировании Европейского Союза. Так, в частности, ст. 39 Договора о ТС и ЕЭП предусматривает обеспечение свободного передвижения граждан государств-участников единого экономического пространства без дискриминации по признаку гражданства и с созданием 
унифицированного правового режима в части трудоустройства, вознаграждения, других условий труда и занятости, включая возможности: свободно передвигаться, занимаясь трудовой деятельностью; свободно пересекать границы и находиться на территории Сторон по паспорту гражданина одной из них; оставаться на территории одного из государств-участников после завершения трудовой деятельности в этом государстве. Эти положения напоминают положения ст. 45 ДФЕС.

Статья 40 Договора о ТС и ЕЭП предусматривает зачет трудового стажа, полученного на территории другого государства-участника, в общий трудовой стаж, в том числе при начислении пенсий и пособий, что закрепляется и в ст. 48 ДФЕС. В статье 42 говорится о проведении единой визовой политики в отношении третьих стран, в том числе в целях предупреждения неконтролируемой миграции, что отдаленно напоминает положения ст. 79 ДФЕС. В статье 39 Договора о ТС и ЕЭП сохранилось упоминание о национальном режиме для граждан государств-участников, постоянно проживающих на территории любой из сторон, а также упрощение процедур принятия и выхода из гражданства. На данном этапе сходство с нормами права ЕС заканчивается формулировками договорных норм, имеющих материальный характер. Детали регулирования слишком различны, но некоторое заимствование европейского опыта международно-правового регулирования трудовой миграции, безусловно, имеет место.

Следует отметить, что большинство положений Договора о ТС и ЕЭП о направлениях сотрудничества в области трудовой миграции берут свою основу в Договоре о создании Экономического Союза 1993 г., который впервые в рамках СНГ отразил желание государств осуществлять сотрудничество в рамках региональной международной организации по типу Европейского Союза (Щур-Труханович 2012). Договор о Евразийском экономическом союзе (КонсультантПлюс 2014) содержит лишь организационные и институциальные положения, он не привносит каких-либо изменений в текст Договора о ТС и ЕЭП, касающийся регионального рынка труда. Тем не менее именно ЕврАзЭС стало площадкой развития региональной интеграции в экономической и иных областях (Galiakberov, Abdullin 2014: 116).

Новая модель интеграционного сотрудничества на Евразийском пространстве была запущена 1 января 2015 г. со вступления в силу Договора о Евразийском экономическом союзе (далее - Договор о ЕАЭС). Договор о ЕАЭС замещает собой соглашения, достигнутые тремя государствами по вопросам ТС и ЕЭП, начиная с 2007 г.

\section{Возможен ли учет опыта права ЕС в области свободного передвижения трудящихся государств-членов ЕАЭС?}

В области правового регулирования трудовой миграции Соглашение о правовом статусе трудящихся-мигрантов и членов их семей (далее - Co- 
глашение о трудящихся-мигрантах), подписанное 19 ноября 2010 г., прекратило свое действие на основании Протокола № 33 к Договору о ЕАЭС, вместо него применяется раздел XXVI «Трудовая миграция» части третьей Договора о ЕАЭС, регламентирующей функционирование единого экономического пространства Союза (Собрание... 2012а). Соглашение о сотрудничестве по противодействию нелегальной трудовой миграции из третьих государств (далее - Соглашение о нелегальной трудовой миграции), подписанное также 19 ноября 2010 г., продолжает действовать в рамках ЕАЭС (Собрание... 2012 b). Рассмотрим отдельные компоненты режима, установленного по отношению к трудящимся-мигрантам в рамках статей 96-98 Договора о ЕАЭС и в Соглашении о нелегальной трудовой миграции, в сравнении с правом ЕС.

В отечественной доктрине международного права и международного частного права при определении правового положения иностранцев говорят о национальном режиме, который рассматривается как общепризнанный (Дмитриева 2012: 180) и отражен в ст. 62 Конституции РФ, а также в других законодательных актах, в частности, ст. 4 Федерального закона № 115-Ф3 «О правовом положении иностранных граждан в Российской Федерации», ст. 11 Трудового кодекса РФ, ст. 1196 Гражданского кодекса РФ. Кроме того, выделяют специальный режим и режим наибольшего благоприятствования (Валеев, Курдюков 2017:214). Соглашение о трудящихся-мигрантах создает режим наибольшего благоприятствования для трудящихся-мигрантов из ЕЭП и выводит их в особую льготную категорию иностранных работников (Ястребова 2014: 336).

Первым важным моментом является определение сферы действия международных договоров ЕАЭС по кругу лиц через определение понятий «трудящийся-мигрант», «трудящийся государства-члена» и, соответственно, «нелегальный трудящийся-мигрант». Если Соглашение о трудящихсямигрантах 2010 г. использовало термин «трудящийся-мигрант», то Договор о ЕАЭС в статье 96 заменяет его на термин «трудящийся государствачлена», дабы показать своеобразие региональной интеграционной модели свободного передвижения рабочей силы по аналогии со свободным передвижением работников внутри ЕС (Бекяшев, Иванов 2014: 129-132). Так, трудящийся государства-члена - это лицо, являющееся гражданином государства одной из сторон, законно находящееся и на законном основании осуществляющее трудовую деятельность на территории государства другой стороны, гражданином которого оно не является и в котором постоянно не проживает. Трудовая деятельность по ст. 96 включает в себя как деятельность на основании трудового договора, так и деятельность по выполнению работ (оказанию услуг) на основании гражданско-правового договора.

В рамках трудового права Европейского Союза, ДФЕС не содержит определения термина «работник». Ст. 1 Регламента 492/2011 (European Union Law 2011) повторяет норму предыдущего Регламента 1612/68 и под 
работником понимает гражданина государства-члена, независимо от места постоянного проживания, который имеет право работать по найму на территории другого государства-члена. Термин «работник» получил расширительное токование в практике Суда ЕC, поскольку речь идет о т.н. автономном понятии права ЕС, имеющем правовое значение исключительно для данного правового комплекса. «Автономные понятия» права ЕС подлежат широкому толкованию, кроме того они призваны регулировать трудовые отношения трансграничного характера и не применяются к чисто внутренним ситуациям (Юмашев, Постникова 2014: 127). Имеющими статус работника для целей свободного передвижения, прежде всего, рассматриваются лица, которые в течение определенного периода времени оказывают услуги за вознаграждение другому лицу под его руководством (Дело 66/85 Lawrie-Blum v. Land Baden-Württemberg [1986]). Как отмечает Кэтрин Барнард, сфера занятости и природа правовых отношений между работодателем и работником несущественны (Barnard 2012: 149).

Кроме того, важное значение для распространения статуса работника на тех или иных лиц имеет выполняемая работа: трудовая деятельность должна быть реальной и эффективной, а не побочной и вспомогательной. Большинство видов деятельности, даже если цель такой деятельности формально противоречит статусу наемного работника (Постовалова 2015:246), отвечают этому требованию, включая профессиональный футбол (Case C-415/93 Union Royale Belge de Société de Football Association v Bosman [1995] ECR I-4921), коммерческий секс (Case C-268/99 Aldona Malgorzata Jany and others v. Staatssecretaris van Justitie [2001] ECR I-8615), ученичество и другие типы профессионального обучения. В том числе работа члена религиозной общины, который выполняет некоторые обязанности по дому, даже не будучи официально платными (только карманные деньги), была признана в качестве «экономической деятельности», а работа - реальной и эффективной (Дело C-196/87 Steymann v. Staatssecretaris van Justitie [1988]). В другом случае трудовая деятельность не была признана реальной и эффективной, поскольку осуществлялась в индивидуальном порядке для достижения цели интеграции бывших наркоманов в общественную жизнь (Дело 344/87 Bettray v. Staatssecretaris van Justitie [1989]. Суд ЕС распространил определение работника также на лиц, потерявших работу и ищущих ee (Barnard 2012: 150), а также при определенных обстоятельствах на лиц самостоятельного труда (Постовалова 2015:248).

В Договоре о ЕАЭС в определении термина «трудящийся государства-члена» большее внимание уделяется законности пребывания, в то время как в праве ЕС презюмируется максимально широкое понимание термина «работник» для целей обеспечения свободного передвижения. В ЕС в рамках широкого подхода свободное передвижение рассматривается не только для работников, но и для неработающих лиц, включая студентов, пенсионеров, а также для граждан третьих стран, законно 
проживающих на территории какого-либо государства-члена. Для целей развития экономической интеграции и обеспечения единого рынка труда в ЕАЭС было бы целесообразно использовать широкое понимание термина «трудящийся государства-члена» через толкование этого термина Судом ЕАЭС с учетом имеющегося опыта в практике Суда ЕС. Впрочем, такое толкование будет иметь рекомендательный характер в силу отсутствия у суда ЕАЭС компетенции по обязательному преюдициальному рассмотрению споров (Kembayev 2016:357), в том числе в области трудовой миграции, а лишь наличия полномочий по принятию рекомендательных заключений (Ispolinov 2013: 230).

Также отличием является срок нахождения на территории принимающего государства: в Договоре о ЕАЭС речь идет только о временном характере нахождения, а право ЕС не ограничивает срок, допуская и поощряя постоянное проживание работников из других государств-членов, чему посвящены положения Директивы 2004/38. Учитывая, что в Договоре о ЕАЭС срок действия трудового договора не ограничивается (European Union Law 2004: п.5 ст. 97), считаем возможным расширение сферы действия Договора, включая в нее трудящихся государств-членов, временно или постоянно проживающих на территории другого государства, нежели государство гражданства.

Определение, данное Соглашением о нелегальной трудовой миграции в рамках ЕЭП не касается граждан Беларуси, Казахстана и России, под нелегальными трудящимися-мигрантами понимаются как граждане третьих государств, так и лица без гражданства, въезжающие (и/или пребывающие) на территорию государства одной из Сторон с целью осуществления трудовой деятельности с нарушением законодательства этого государства, либо осуществляющие трудовую деятельность на территории государства одной из Сторон с нарушением законодательства этого государства. Отметим, что право ЕС рассматривает вопрос о незаконной трудовой миграции также в отношении незаконно пребывающих граждан третьих стран. Незаконное пребывание по п. 3.2. Директивы 2008/115 об общих стандартах и процедурах в государствах-членах для возвращения незаконно пребывающих граждан третьих стран «означает присутствие на территории государства-члена гражданина третьей страны, который не отвечает или перестал отвечать условиям въезда, указанным в статье 5 Шенгенского кодекса о границах или другим условиям въезда, пребывания или проживания в этом государстве-члене» (European Union Law 2008).

Директива 2009/52 об установлении минимальных стандартов в отношении санкций и мер к работодателям незаконно пребывающих граждан третьих стран ввела запрет работы незаконно пребывающих граждан третьих стран (European Union Law 2009: ст. 3), жестко увязав вопрос трудовой деятельности с фактом незаконного пребывания лица. Цель такого регулирования состоит в закреплении мер воздействия на работодателей, 
а также в обеспечении защиты лиц, ставших жертвами торговли людьми в результате незаконной миграции. Такой подход, как мы видим, в целом совпадает с подходом Соглашения о нелегальной трудовой миграции 2010 г., не допускающего осуществление трудовой деятельности с нарушением законодательства принимающего государства, однако запрет любого трудоустройства незаконно пребывающих мигрантов в праве ЕС сформулирован прямо и подлежит закреплению во внутреннем законодательстве государствчленов ЕС, хотя исключения также предусмотрены в ст. 3 для жертв торговли людьми, когда выдворение откладывается. Стоит отметить, что в последние годы под воздействием ООН и Совета Европы ЕС стремится использовать в своих документах термин «нерегулярная» (irregular) миграция вместо «незаконная» (illegal), делая акцент на защите прав таких мигрантов.

Деятельность, связанная с привлечением к трудовой деятельности граждан государств-членов ЕАЭС, осуществляется работодателями государства трудоустройства без учета ограничений по защите национального рынка труда, а трудящимся-мигрантам не требуется получения разрешений на осуществление трудовой деятельности на территориях государств Сторон (ст. 97 Договора о ЕАЭС). На территории Российской Федерации такой порядок уже применяется по отношению к гражданам Республики Беларусь во исполнение п. 1 Решения Высшего Совета Сообщества Беларуси и России от 22 июня 1996 № 4 «О равных правах граждан на трудоустройство, оплату труда и предоставление других социально-трудовых гарантий» (Высший Совет... 1998). Несмотря на отмену разрешительного порядка трудоустройства в Договоре о ЕАЭС, указанный документ не содержит общего положения о запрете дискриминации по признаку гражданства, в то время как данный принцип является основой режима свободы передвижения работников внутри ЕС (статьи 18, 45 ДФЕС) и он был отражен в более ранних «евразийских» соглашениях, в частности, в Договоре о ТС и ЕЭП. Причем отсутствие запрета дискриминации не помешало включить в текст договора условие об исключениях из него. Договор о ЕАЭС в п. 2 ст. 97 допускает установление ограничений в отношении осуществляемой трудящимися государств-членов трудовой деятельности, рода занятий и территории пребывания в целях обеспечения национальной безопасности (в том числе в отраслях экономики, имеющих стратегическое значение) и общественного порядка, которые не могут рассматриваться как дискриминация и ограничение прав и свобод.

Такое умолчание о принципе недискриминации вряд ли можно назвать случайным, оно связано с общей неразработанностью антидискриминационного законодательства в государствах ЕАЭС, в частности, в России. С точки зрения соблюдения принципа недискриминации Россия не имеет достаточной нормативно-правовой базы для защиты прав мигрантов в рамках единого миграционного пространства Евразийского экономического союза (Прохорова 2012). Российское законодательство 
содержит особый подход по отношению к иностранным работникам: Федеральный закон № 115-Ф3 от 25.07.2002 «О правовом положении иностранных граждан в Российской Федерации» исходит из принципа приоритетного использования национальных трудовых ресурсов с учетом ситуации на рынке труда (ст. 18), а ст. 3 Трудового Кодекса РФ в редакции Федерального закона № 204-Ф3 от 23.07.2013 не признает дискриминацией установление различий, исключений, предпочтений, а также ограничение прав работников, которые установлены в соответствии с законодательством о правовом положении иностранных граждан в Российской Федерации.

По мнению аналитиков Российского совета по международным делам формирование общего рынка труда - наиболее сложный вопрос региональной интеграции. Несмотря на то, что с момента распада СССР Россия поддерживала безвизовый режим со странами СНГ, в отношении рынка труда она всегда придерживалась протекционистской политики (Троицкая 2012). Существенным отличием правового регулирования трудовой миграции в рамках ЕАЭС от соответствующей модели регулирования в ЕС является практически полное отсутствие норм Договора о ЕАЭС и иных многосторонних региональных международных соглашений государств-членов по вопросу о трудовой миграции граждан третьих стран, в то время как в праве ЕС существует серьезная правовая база такого регулирования. В частности, правовой основой в ЕС выступают ст.ст. 77, 79 ДФЕС, нормы международных соглашений ЕС с другими странами о Европейском экономическом пространстве, об ассоциации, о партнерстве и сотрудничестве. На уровне вторичного законодательства осуществляется правовое регулирование передвижения граждан третьих стран. Льготный режим передвижения создан для высококвалифицированных мигрантов - Директива 2009/50/ЕС об установлении условий въезда и пребывания граждан третьих стран в целях высококвалифицированной работы ввела особый статус для обладателей т.н. «европейской голубой карты», вида на жительство Европейского Союза сроком действия до четырех лет с возможностью продления.

Право на передвижение и проживание граждан третьих стран закрепляется в таких актах как: Директива Совета 2003/109/ЕС о статусе граждан третьих стран, проживающих на долгосрочной основе, Директива Совета 2003/86/ЕС о праве на семейное воссоединение, Директива 2001/98/ЕС о единой процедуре подачи заявки за единым разрешением для граждан третьих стран на проживание и работу на территории государства-члена и об общем перечне прав для работников из третьих стран, законно проживающих в государстве-члене, а также Директива Парламента и Совета 2016/801/ЕС об условиях въезда и проживания граждан третьих стран в целях научных исследований, стажировок, волонтерской деятельности, обмена студентами или образовательных проектов, а также работы по программе au pair. Впрочем, нельзя сказать, что международно-правовое воздействие в данной области полностью отсутствует на Евразийском 
пространстве, оно реализуется через соглашения, заключенные в рамках СНГ, а также на двустороннем уровне о безвизовом передвижении и взаимных поездках граждан, о трудовой миграции, о правовом статусе трудящихся-мигрантов и членов их семей, об организованном наборе.

\section{Заключение}

Учредительные документы о создании СНГ, а также договорные акты, закрепляющие углубленное сотрудничество отдельных государств и предшествующие созданию Евразийского экономического союза содержат формулировки, позволяющие сделать вывод о желании разработчиков учесть опыт европейской интеграции. В то же время, несмотря на влияние правового опыта Европейского Союза в отношении формирующейся правовой системы Содружества, особенно в плане создания Экономического Союза и общего экономического пространства в рамках Таможенного союза и Евразийского экономического сообщества, реализация соответствующих договорных положений существенно отличается от правовой модели свободного передвижения в праве ЕС.

Отражение в международно-правовых актах Евразийского региона базовых правил формирования международного регионального рынка труда, связанное с развитием интеграционных начал, главным образом, в Евразийском Экономическом Сообществе, до создания ЕАЭС выступало больше как желаемое, чем действительное. Термин «трудящийся государства-члена», используемый в Договоре о ЕАЭС, при всем сходстве с термином «работник» в праве ЕС, в своем определении содержит явный акцент на законность пребывания, в то время как нормативные акты ЕС и особенно правоприменительная практика Суда ЕС сформировали максимально широкое понимание термина «работник» для обеспечения свободного передвижения. Представляется, что для развития экономической интеграции и обеспечения единого рынка труда в ЕАЭС было бы целесообразно использовать широкое понимание термина «трудящийся государствачлена» через рекомендательное толкование этого термина Судом ЕАЭС, принимая во внимание имеющийся опыт в практике Суда ЕC, а также учитывая правовые традиции государств-членов ЕАЭС.

Поскольку в Договоре о ЕАЭС срок действия трудового договора не ограничивается (п. 5 ст.97), считаем возможным расширение сферы действия Договора по аналогии с правом ЕС, включая в нее трудящихся государств-членов, временно или постоянно проживающих на территории другого государства, нежели государство гражданства. В рамках определения сферы действия актов ЕАЭС в отношении незаконно пребывающих граждан третьих стран для целей более прозрачного регулирования целесообразно использовать опыт ЕС по запрету трудовой деятельности для нерегулярных трудовых мигрантов. Вместе с тем Договор о ЕАЭС должен 
быть дополнен положением о запрете дискриминации трудящихся государств-членов по признаку гражданства по аналогии со статьями 18, 45 ДФЕС и ст. 39 Договора о ТС и ЕЭП 1999 г. Кроме того, в законодательстве Российской Федерации, прежде всего, в Федеральном законе № 115-Ф3 требуется ввести специальную категорию лиц: иностранные граждане из государств-членов Евразийского экономического союза, для которой предусматриваются исключения из ограничительного режима по всем условиям ст.ст. 96-98 Договора о ЕАЭС. Следует рекомендовать Евразийской экономической комиссии инициировать внесение в Договор о ЕАЭС положений о правовом регулировании трудовой миграции граждан третьих стран с учетом опыта ЕС и целесообразности выделения отдельных категорий трудовых мигрантов, для которых может быть установлен специальный режим нахождения на территории государства-члена ЕАЭС и осуществления там трудовой деятельности.

Представляется также необходимым сближение законодательств государств-членов ЕАЭС в области правового регулирования трудовой миграции, учитывая опыт Европейского Союза, несмотря на то, что на текущий момент ЕАЭС отказывается формулировать даже в качестве цели гармонизацию трудового права. В рамках Евразийского экономического союза может быть найдена желаемая модель интеграции, которая станет тем более эффективной, чем больше она сможет перенять лучший опыт, накопленный в других региональных интеграционных объединениях, таких как ЕС, при учете правовых традиций, сложившихся на Евразийском пространстве за последние десятилетия.

\section{Выражение признательности}

Настоящая статья подготовлена в рамках Центра превосходства Жана Монне в области европейских исследований VOICES +, финансируемого Программой Erasmus + Европейского Союза. В публикации отражено только авторское мнение и Комиссия не может нести ответственность за любое использование информации, содержащейся в ней.

\section{Список источников}

Бекяшев Д.К., Иванов Д.В. (2014) Международно-правовое регулирование вынужденной и трудовой миграции. М.: Проспект.

Бюллетень международных договоров (1995) Договор об Экономическом Союзе от 24 сентября 1993 г. Бюллетень международных договоров, (1): 3.

Валеев Р. М., Курдюков Г.И. (ред.) (2017) Международное право. М.: Статут.

Высший Совет Сообщества Беларуси и России (1998) Решение «О равных правах граждан на трудоустройство, оплату труда и предоставление других социальнотрудовых гарантий», № 4, 22 июня 1996 г. Российская газета, (29). 
Дмитриева Г.К. (ред.) (2012) Международное частное право. М.: Проспект.

Европейский Союз (1994) Документы Европейского Союза. Том 1. М.: Междунар. изд. группа «Право».

КонсультантПлюс (2014) Договор о Евразийском экономическом союзе от 29 мая 2014 г. Доступно по ссылке http://www.consultant.ru/document/cons_doc_LAW_163855/ (дата обращения: 25 октября 2018).

Лушникова М. В., Рахманкулов К. С., Томашевский К. Л. (ред.) (2018) Евразийское трудовое право. М.: Проспект.

Постовалова Т. А. (2015) Трудовое право Европейского Союза: теория и практика. М.: Проспект.

Прохорова А. (2012) Евразийский Союз и будущее миграционной политики России. Антидискриминационное законодательство как условие успешной евразийской интеграции. «Демоскоn Weekly». Доступно по ссылке: http://demoscope.ru/weekly/2012/0513/analit05.php (дата обращения: 14 июля 2018).

Российская газета (1993) Устав Содружества Независимых Государств, 22 января 1993 г. Российская газета, 12 февраля 1993 г.

Собрание законодательства РФ (2001) Договор о Таможенном союзе и Едином экономическом пространстве, 26 февраля 1999 г. Собрание законодательства РФ, (42), ст. 3983.

Собрание законодательства РФ (2012а) Соглашение о правовом статусе трудящихся-мигрантов и членов их семей от 19 ноября 2010 г. Собрание законодательства $P \Phi,(5)$, ст. 546.

Собрание законодательства РФ (2012b) Соглашение о сотрудничестве по противодействию нелегальной трудовой миграции из третьих государств от 19 ноября 2010 г. Собрание законодательства РФ, (5), ст. 541.

Тихомиров Ю. А. (1993) Национальные законодательства и международное право: параллели и сближения. Московский журнал международного права, (3): 80-88.

Троицкая О. (2012) Евразийский союз и миграция. Российское агентство по международным делам, 25.06.2012. Доступно по ссылке: http://russiancouncil.ru/ inner/?id_4=544\#top (дата обращения: 13 июля 2018).

Щур-Труханович Л.В. (2012) Единое экономическое пространство России, Беларуси и Казахстана как форма, тип, этап международной экономической интеграции и объект международных договоров. Доступно по ссылке: https://wiselawyer.ru/ poleznoe/60177-edinoe-ehkonomicheskoe-prostranstvo-rossii-belarusi-kazakhstana-forma (дата обращения: 13 июля 2018).

Юмашев Ю.М., Постникова Е. В. (2014) Экономическое право Европейского Союза. М.: Норма.

Ястребова А.Ю. (2014) Международно-правовые механизмы регулирования миграции: доктринальные подходы и опьт Российской Федерации. М.: ВАКО. 
Barnard C. (2012) EU Employment Law. Oxford: Oxford University Press.

European Union Law (2004) Directive 2004/38/EC of the European Parliament and of the Council of 29 April 2004 on the right of citizens of the Union and their family members to move and reside freely within the territory of the Member States amending Regulation (EEC) No 1612/68 and repealing Directives 64/221/EEC, 68/360/EEC, 72/194/EEC, 73/148/EEC, 75/34/EEC, 75/35/EEC, 90/364/EEC, 90/365/EEC and 93/96/EEC. Official Journal of the European Union (158): 77-123.

European Union Law (2008) Directive 2008/115/EC of the European Parliament and of the Council of 16 December 2008 on common standards and procedures in Member States for returning illegally staying third-country nationals. Official Journal of the European Union, (348): 98-107.

European Union Law (2009) Directive 2009/52/EC of the European Parliament and of the Council of 18 June 2009 providing for minimum standards on sanctions and measures against employers of illegally staying third-country nationals. Official Journal of the European Union (168): 24.

European Union Law (2011) Regulation (EU) No 492/2011 of the European Parliament and of the Council of 5 April 2011 on freedom of movement for workers within the Union. Official Journal of the European Union, (141): 1-12.

Galiakberov A., Abdullin A. (2014) Theory and practice of regional integration based on the EurAsEC model (Russian point of view). Journal of Eurasian Studies, (5): 116-121.

Ispolinov A. S. (2013) First Judgments of the Court of the Eurasian Economic Community: Reviewing Private Rights in a New Regional Agreement. Legal Issues of Economic Integration, 40 (3): 225-246.

Kembayev Zh. (2016) The Court of the Eurasian Economic Union: An Adequate Body for Facilitating Eurasian Integration. Review of Central and East European Law, (41):342-367. 
Rustem Davletgildeev

\title{
INTERNATIONAL LEGAL REGULATIONS OF LABOUR MIGRATION IN THE EURASIAN REGION: A TENTATIVE ATTEMPT AT APPROXIMATING THE EU'S FREE MOVEMENT OF WORKERS?
}

\begin{abstract}
The international legal regulation of labour migration within the framework of regional integration in the European Union and the Eurasian Economic Union is characterized by significant uniqueness and differs from the universal models that have developed within the UN, the ILO and others. This article compares the terms used in the EAEU Treaty with the term 'worker', developed within the framework of the practice of the European Court of Justice, and formulates separate proposals for the integration institutions of the EAEU to incorporate the experience of EU law in ensuring the free movement of workers. As a result of the study, the following conclusions were made. Despite the influence of the legal experience of the European Union on the emerging legal system of the CIS, the implementation of the relevant treaty provisions differs significantly from the legal model of free movement in EU law. It seems that for the purposes of developing economic integration and ensuring a single labour market in the EAEU, it would be useful to use a broad understanding of the term 'Worker of a Member State' and, thus, benefit from the EU experience of prohibiting labour activities for irregular migrant workers. The EAEU Treaty could also be effectively supplemented with discrimination prohibitions for workers of the member states on the basis of nationality, as well as provisions to the Treaty on the EAEU on the legal regulation of labour migration for third-country nationals. The desired integration model within the EAEU would be even more effective if it incorporated the best experience gained in other regional integrations with more experience, such as the EU.
\end{abstract}

Key words: Labour migration, a worker of a member state, the Eurasian Economic Union, the European Union, freedom of movement of workers

DOI: 10.17323/727-0634-2018-16-4-595-610

\section{References}

Barnard C. (2012) EU Employment Law. Oxford: Oxford University Press.

Bekyashev D. K., Ivanov D. V. (2014) Mezhdunarodno-pravovoe regulirovanie vynuzhdennoy i trudovoy migratsii [International Legal Regulation of the Forced and Labour Migration]. Moscow: Prospekt.

Rustem Davletgildeev - Doctor of Law, Docent, Academic Coordinator of the Jean Monnet Center of Excellence in European Studies VOICES+, Deputy Dean of the Law Faculty, Kazan Federal University, Kazan, Russian Federation. Email: roustem.davletguildeev@kpfu.ru 
Bulletin of International Treaties (1995) Dogovor ob Ekonomicheskom Soyuze [Treaty on the Economic Union of September 24, 1993]. Byulleten' mezhdunarodnykh dogovorov [Bulletin of International Treaties], (1): 3.

Collected Legislation of the Russian Federation (2001) Dogovor o Tamozhennom soyuze i Edinom ekonomicheskom prostranstve [Treaty on the Customs Union and the Common Economic Area, February 26, 1999]. Sobranie zakonodatel'stva RF [Collected Legislation of the Russian Federation], (42): art. 3983.

Collected Legislation of the Russian Federation (2012a) Soglashenie o pravovom statuse trudyashchikhsya-migrantov i chlenov ikh semey [Agreement on the Legal Status of Migrant Workers and Members of Their Families on November 19, 2010]. Sobraniye zakonodatel'stva $R F$ [Collection of the Legislation of the Russian Federation], (5): art. 546.

Collected Legislation of the Russian Federation (2012b) Soglashenie o sotrudnichestve po protivodeystviyu nelegal'noy trudovoy migratsii iz tret'ikh gosudarstv [Agreement on Cooperation in Countering Illegal Labour Migration from Third Countries of November 19, 2010]. Sobraniye zakonodatel'stva RF [Collection of the Legislation of the Russian Federation], (5): art. 541.

Consultant.ru (2014) Dogovor o Evraziyskom ekonomicheskom soyuze [Treaty on the Eurasian Economic Union of May 29, 2014]. Available at: http://www.consultant.ru/document/ cons_doc_LAW_163855/(accessed 25 October 2018).

Dmitrieva G.K. (ed.) (2012) Mezhdunarodnoe chastnoe parvo [International Private Law]. Moscow: Prospekt.

European Union (1994) Dokumenty Evropeyskogo Soyuza. Tom 1 [The Documents of the European Union. Volume 1]. Moscow: Pravo.

European Union Law (2004) Directive 2004/38/EC of the European Parliament and of the Council of 29 April 2004 No 1612/68 and repealing Directives 64/221/EEC, 68/360/EEC, 72/194/EEC, 73/148/EEC, 75/34/EEC, 75/35/EEC, 90/364/EEC, 90/365/EEC and 93/96/ EEC. Official Journal of the European Union (158): 77-123.

European Union Law (2008) Directive 2008/115/EC of the European Parliament and of the Council of 16 December 2008 on Common Standards and Procedures in Member States for Returning Illegally Staying Third-country Nationals. Official Journal of the European Union, (348): 98-107.

European Union Law (2009) Directive 2009/52/EC of the European Parliament and of the Council of 18 June 2009 Providing for Minimum Standards on Sanctions and Measures against Employers of Illegally Staying Third-country Nationals. Official Journal of the European Union (168): 24.

European Union Law (2011) Regulation (EU) No 492/2011 of the European Parliament and of the Council of 5 April 2011 on Freedom of Movement for Workers within the Union. Official Journal, (141): 1-12.

Ispolinov A. S. (2013) First Judgments of the Court of the Eurasian Economic Community: Reviewing Private Rights in a New Regional Agreement. Legal Issues of Economic Integration, 40 (3): 225-246.

Kembayev Zh. (2016) The Court of the Eurasian Economic Union: An Adequate Body for Facilitating Eurasian Integration. Review of Central and East European Law, (41):342-367. 
Postovalova T. A. (2015) Trudovoe pravo Evropeyskogo Soyuza: teoriya i praktika [Labour Law of the European Union: Theory and Practice]. Moscow: Prospekt.

Prokhorova A. (2012) Evraziyskiy Soyuz i budushchee migratsionnoy politiki Rossii. Antidiskriminatsionnoe zakonodatel'stvo kak uslovie uspeshnoy evraziyskoy integratsii [The Eurasian Union and the Future of Russia's Migration Policy. Anti-discrimination Legislation as a Condition for Successful Eurasian Integration]. Demoskop Weekly [Demoscope Weekly]. Available at: http://demoscope.ru/weekly/2012/0513/analit05.php (accessed 14 July 2018).

Rossiyskaya gazeta (1993) Ustav Sodruzhestva Nezavisimykh Gosudarstv [Charter of the Commonwealth Of Independent States from January 22, 1993]. Rossiyskaya gazeta [Russian Newspaper], February 12.

Shchur-Trukhanovich L.V. (2012) Edinoe ekonomicheskoe prostranstvo Rossii, Belarusi i Kazakhstana kak forma, tip, etap mezhdunarodnoy ekonomicheskoy integratsii i ob"ekt mezhdunarodnykh dogovorov [The Single Economic Space of Russia, Belarus and Kazakhstan as a Form, Type, Stage of International Economic Integration and the Object of International Treaties]. Available at: https://wiselawyer.ru/poleznoe/60177-edinoe-ehkonomicheskoe-prostranstvo-rossii-belarusi-kazakhstana-forma (accessed 13July 2018).

Supreme Council of Belarus and Russia (1998) Reshenie 'O ravnykh pravakh grazhdan na trudoustroystvo, oplatu truda i predostavlenie drugikh sotsial'no-trudovykh garantiy' [The Decision of 'On Equal Rights of Citizens to Employment, Pay and the Provision of Other Social and Labour Guarantees' of June 22, 1996 No. 4]. Rossiyskaya gazeta [Russian Newspaper], (29), February 14.

Tikhomirov Yu.A. (1993) Natsional'nye zakonodatel'stva i mezhdunarodnoe pravo: paralleli i sblizheniya [National Legislation and International Law: Parallels and Convergence]. Moskovskiy zhurnal mezhdunarodnogo prava [Moscow Journal of International Law], (3): 80-88.

Troitskaya O. (2012) Evraziyskiy soyuz i migratsiya [Eurasian Union and Migration]. Rossiyskoe agentstvo po mezhdunarodnym delam [Russian Agency for International Affairs], 25.06.2012. Available at: http://russiancouncil.ru/inner/?id_4=544\#top (accessed 14 July 2018).

Valeev R. M., Kurdyukov G. I. (eds.) (2017) Mezhdunarodnoe parvo [International Law]. Moscow: Statut.

Yastrebova A. Yu. (2014) Mezhdunarodno-pravovye mekhanizmy regulirovaniya migratsii: doktrinal'nye podkhody i opyt Rossiyskoy Federatsii [International Legal Mechanisms of Migration Regulation: Doctrinal Approaches and the Experience of the Russian Federation]. Moscow: VAKO.

Yumashev Yu.M., Postnikova E. V. (2014) Ekonomicheskoe pravo Evropeyskogo Soyuza [Economic Law of the European Union]. Moscow: Norma. 